\title{
Evolution of rheologically heterogeneous salt structures: a case study from the NE Netherlands
}

\author{
A. F. Raith ${ }^{1}$, F. Strozyk ${ }^{2}$, J. Visser ${ }^{3}$, and J. L. Urai ${ }^{1}$ \\ ${ }^{1}$ RWTH Aachen University, Energy- and Mineral Resources Group, Structural Geology, Tectonics and \\ Geomechanics, Aachen, Germany \\ ${ }^{2}$ RWTH Aachen University, Energy and Mineral Resources Group, Geological Institute, Aachen, Germany \\ ${ }^{3}$ Nedmag Industries Mining \& Manufacturing B.V., Veendam, the Netherlands \\ Correspondence to: A. F. Raith (a.raith@ged.rwth-aachen.de)
}

Received: 27 May 2015 - Published in Solid Earth Discuss.: 1 July 2015

Revised: 25 November 2015 - Accepted: 26 November 2015 - Published: 15 January 2016

\begin{abstract}
The growth of salt structures is controlled by the low flow strength of evaporites and by the tectonic boundary conditions. The potassium-magnesium salts (K-Mg salts) carnallite and bischofite are prime examples of layers with much lower effective viscosity than halite: their low viscosity presents serious drilling hazards but also allows squeeze solution mining. In contrast, intrasalt anhydrite and carbonate layers (stringers) are much stronger than halite. These rheological contrasts within an evaporite body have an important control on the evolution of the internal structure of salt, but how this mechanical layering affects salt deformation at different scales is not well known. In this study, we use high-resolution 3-D seismic and well data to study the evolution of the Veendam and Slochteren salt pillows at the southern boundary of the Groningen High, northern Netherlands. Here the rock salt layers contain both the mechanically stronger Zechstein III Anhydrite-Carbonate stringer and the weaker $\mathrm{K}-\mathrm{Mg}$ salts, thus we are able to assess the role of extreme rheological heterogeneities on salt structure growth. The internal structure of the two salt pillows shows areas in which the K-Mg salt-rich ZIII 1 b layer is much thicker than elsewhere, in combination with a complexly ruptured and folded ZIII Anhydrite-Carbonate stringer. Thickness maps of supra-salt sediments and well data are used to infer the initial depositional architecture of the K-Mg salts and their deformation history. Results suggest that faulting and the generation of depressions on the top Zechstein surface above a Rotliegend graben caused the local accumulation of bittern brines and precipitation of thick K-Mg salts. During the first phase of salt flow and withdrawal from the Veendam area,
\end{abstract}

under the influence of differential loading by Buntsandstein sediments, the ZIII stringer was boudinaged while the lens of $\mathrm{Mg}$ salts remained relatively undeformed. This was followed by a convergence stage, when the K-Mg salt-rich layers were deformed within the inflating salt pillows. This deformation was strongly disharmonic and strongly influenced by folding of the underlying, ruptured ZIII stringer, leading to thickening and internal deformation of the $\mathrm{K}-\mathrm{Mg}$ salt layers.

\section{Introduction}

Salt bodies are often depicted as a homogeneous mass of mechanically weak rock salt with deformation driven by buoyancy, differential loading, or gravity gliding (Jackson and Talbot, 1986; Hudec and Jackson, 2007). Our understanding of large-scale salt tectonics has grown tremendously over the last century (e.g. Jackson et al., 1996; Warren, 2006), but the internal deformation of evaporites, as can be observed in outcrops, mines and surface exposures (Jackson et al., 1990), is less well known. Our knowledge of this domain is making some progress, because the internal layering of salt bodies can now be studied at high resolution using modern industrial 3-D seismic reflection data (Van Gent et al., 2011; Cartwright et al., 2012; Fiduk and Rowan, 2012; Strozyk et al., 2012, 2014; Jackson et al., 2014, 2015). In addition, improvements in geomechanical modeling techniques has allowed major advances to be made (Chemia et al., 2008; Albertz et al., 2010; Albertz and Ings, 2012; Goteti et al., 2012; Li et al., 2012a, b). 
Evaporites like carbonates and sulfates (anhydrite, polyhalite, tachydrite), and the $\mathrm{K}-\mathrm{Mg}$ chlorides bischofite $\left(\mathrm{MgCl}_{2} \times 6 \mathrm{H}_{2} \mathrm{O}\right)$ and carnallite $\left(\mathrm{KMgCl}_{3} \times 6 \mathrm{H}_{2} \mathrm{O}\right)$, are rheologically and mechanically different from the polycrystalline halite and may impact the internal deformation of salt structures (Geluk, 1998; Strozyk et al., 2014). Compared to rock salt, the effective viscosity of $\mathrm{K}$ - and $\mathrm{Mg}$-salts is up to three orders of magnitude lower (van Eekelen et al., 1981; Urai, 1983; Urai ,1985; Urai and Boland, 1985; Urai, 1987; Urai et al., 2008; Spiers et al., 1983; Langbein, 1987; Scott Duncan and Lajtai, 1993; Schenk and Urai, 2005), while anhydrite and carbonates have much higher viscosity than rock salt and thus form buckle folds during compression. Furthermore, anhydrite and carbonates are brittle, thus they may rupture in extension or compression (Müller et al., 1981). The interaction of layers with such contrasts in viscosity and rheology during deformation must lead to the development of complex fold and boudin structures. At the meso-scale, these complex internal geometries in layered evaporites are documented in mine galleries and in drill cores (Martini, 1953; Siemeister, 1969; Bornemann and Fischbeck, 1991; Burliga, 1996; Zirngast, 1996; Behlau and Mingerzahn, 2001; Bornemann et al., 2008; Schléder et al., 2008; Hammer et al., 2014). K-Mg salt-rich layers typically show complex, internal folding on the meter to millimeter scale, even if the entire package of layered evaporites is less deformed.

The role of high-viscosity, brittle-ductile layers (also called stringers) in salt deformation has been studied using 3-D seismic data (Van Gent et al., 2011; Cartwright et al., 2012; Fiduk and Rowan, 2012; Jackson et al., 2014, 2015; Strozyk et al., 2014), laboratory experiments, analogue models, and numerical modeling. More specifically, these techniques have been used to understand the complex folds, faults, and boudinage of stringers as a result of deformation of the surrounding salt. Deformation experiments on layered salt show the influence of different rheologies and the mechanics during stringer extension (Liang et al., 2007; Zulauf et al., 2010). Additionally, analogue and numerical models described the evolution of salt flow and stringer deformation (Jackson and Talbot, 1989; Koyi, 2001; Talbot and Aftabi, 2004; Zulauf and Zulauf, 2005; Chemia et al., 2008, 2009; Brun and Mauduit, 2009; Cartwright et al., 2012; Li et al., 2012a, b; Dooley et al., 2015).

In contrast, we have a poorer understanding of the influence of low-viscosity layers of K-Mg salts. In this study we focus on bischofite and carnallite, although we note that other salts like tachydrite have also a very low viscosity, which have been described in evaporites offshore Brazil (Poiate et al., 2006). The low viscosity of deeply buried $\mathrm{K}-\mathrm{Mg}$ salts combined with their high solubility is a well-known source of drilling problems and casing instability (Williamson et al., 1998). On the other hand, carnallite and bischofite are economically interesting and are mined in a number of locations (Vysotskiy and Kislik, 1987; Cerqueira et al., 1997).
There are a few known bischofite deposits with economically significant thicknesses worldwide, these occur in the Caspian and Kaidak basins in Kazakhstan, the DneiperDonets and Pripyat in Ukraine, the Gabon and Congo basins on the African platform, the Sergipe Basin in Brazil and the West European basin (Vysotskiy and Kislik, 1987). One of these rare occurrences of thick bischofite layers occurs on the southern edge of the Groningen High in the NE Netherlands, where it is solution mined by the squeeze mining technique (Fokker, 1995). Bischofite is the last mineral precipitating during a full evaporation cycle (Lotze, 1957; Warren, 2006). For its precipitation out of bittern brines, extremely arid conditions are required. Seawater refreshing events in salt basins normally prevent the deposition of bischofite or dissolve it, while carnallite is more frequently formed (Borchert and Muir, 1964). Besides climate, tectonic processes that change the surface morphology play an important role in the depositional architecture of evaporites (Geluk et al., 2000).

In this project we studied two salt pillows, the Veendam Pillow and Slochteren Pillow in the NE-Netherlands. Here, meter-thick layers of carnallite and bischofite were discovered in the Veendam Pillow in the 1970s (Coelewij et al., 1978). Today the K-Mg salts are produced by NEDMAG Industries using the squeeze mining technique (cf. Geluk et al., 2007). The bischofite layers in the Veendam Pillow are part of uppermost Zechstein III cycle, interbedded with carnallite and halite. Coelewij et al. (1978) studied this structure based on 2-D seismic data and data from wells (VDM-1 to VDM-4), which are located on the eastern flank of the Veendam Pillow. The local Top Salt geometry and the occurrence of thick K-Mg salts were interpreted to be the result of a combination of preferential and differential salt flow. Preferential flow is caused by differences in salt viscosity: for example due to higher temperature in the lower part of the Zechstein, this interval takes up most of the strain, while the upper section folds with much less internal strain. Differential flow is caused by differences in viscosity between layers leading to local strain differences. The result of preferential flow was interpreted to cause the strong thickness variation in the lower ZII halite. In the top part of the Zechstein section, ZIII layers of strongly different composition and viscosities are present. The high viscosity contrast between the layers was proposed to lead to strain concentrated in the softer carnallite and bischofite-rich layers. The result is the formation of "sub-pillows" of low-viscosity evaporites during halokinesis. While these interpretations represented the state of the art in the seventies, the role that the primary sedimentary architecture had on the initial thickness differences was not addressed, and no quantitative analysis or prediction of the "sub-pillows" was provided.

In summary, studying the deformation of evaporites with extreme mechanical stratification will contribute to our understanding of salt tectonics, by exploring how the original compositional variations control rheology and styles of salt structures that form. Furthermore, it will contribute to explo- 
ration and production of potassium-magnesium salts by helping predict lithologies that often lead to drilling problems. In addition, it contributes to developing techniques that will assist in predicting the internal structure of potential nuclear waste repositories in salt (Gärtner et al., 2008; Kukla et al., 2011).

The aim of this study is to gain a better understanding of the initial architecture and structural evolution of layered evaporite deposits, focusing on $\mathrm{K}-\mathrm{Mg}$ salts and on the role of the anhydrite-carbonate stringer in the formation of intrasalt structure.

\section{Geological setting}

The study area is $10 \mathrm{~km}$ southeast of the city of Groningen, in the area between Veendam and Slochteren in the NE Netherlands. Geologically, the area is located at the southernmost edge of the Groningen High (Fig. 1), between the northwestsoutheast trending Lauwerszee Trough in the west and the Lower Saxony Basin in the southeast (Fig. 1). As part of the Lower Permian Basin it has a complex geological history, with multiple tectonic phases of extension, compression, and halokinesis (Ziegler, 1978; Mohr et al., 2005; De Jager, 2007; Geluk et al., 2007b). This complex history can be summarized in four main tectonic phases (De Jager, 2007): (1) The Paleozoic Caledonian and Variscian orogenies caused by the assembly of the Pangea supercontinent, (2) rifting during the breakup of Pangea in the Mesozoic, (3) the collision of Africa and Europe that led to the Alpine inversion during the late cretaceous and Early Tertiary, and (4) the development of the Rhine Graben rift system from the Oligocene to recent times. Key structural processes included the formation and reactivation of basement faults, deformation of Zechstein salts, and strongly decoupled extensional and transpressional faulting in the suprasalt sediments. Halokinesis is interpreted to have been triggered by reactivation of basement faults, which led to differential loading and salt withdrawal (Geluk et al., 2000).

The subsalt Permian Rotliegend is strongly deformed by E-W and N-S to NNW-SSE striking normal and strike-slip faults that form a network of graben to half-graben structures (Fig. 1; also see De Jager, 2007; Geluk, 2007b; Biehl et al., 2014). The Zechstein section in the study area contains fully developed Z-I to Z-IV cycles. The thin and well-stratified ZI and lower ZII sequences are seismically harmonic with the Rotliegend-Zechstein contact, and are mechanically considered to be part of the subsalt. A prominent high-amplitude reflector commonly interpreted as "Base Salt" represents the transition from the ZII salt to Top ZIIC carbonates (Figs. 2 and 3). The thickness of the overlaying, seismically chaotic to transparent ZII rock salt varies from ca. $50 \mathrm{~m}$ below salt withdrawal basins to up to $1.8 \mathrm{~km}$ in flanking salt pillows. In general, the ZII salts are mainly composed of halite $(>95 \%$; Geluk et al., 2000).
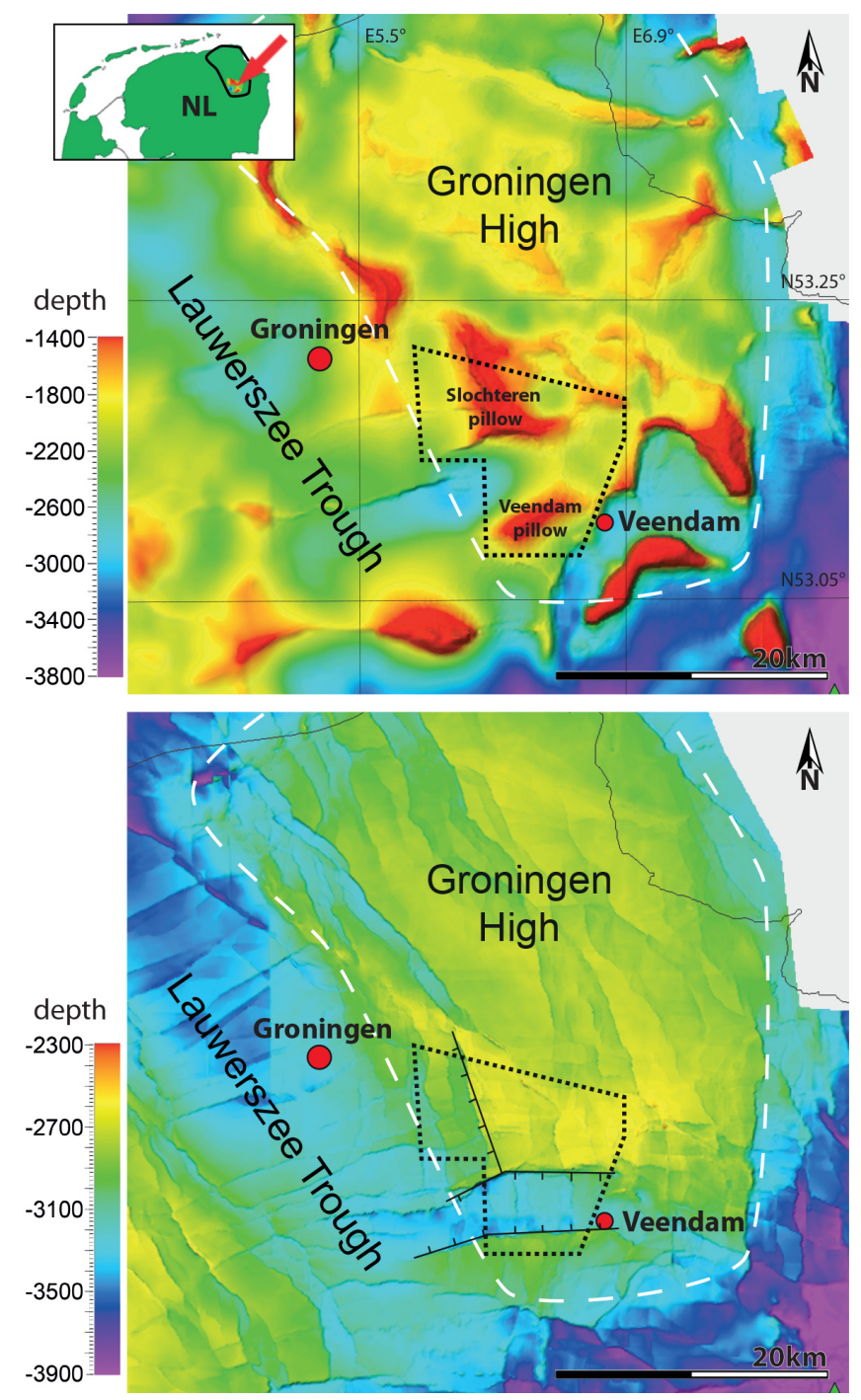

Figure 1. (a) Top Salt map from the Groningen High (outline marked by white dotted line) and surrounding areas (modified after Strozyk et al., 2014). The black dotted line indicates the outlines of 3-D seismic volumes covering the study area; (b) base Salt map from the Groningen High and surrounding areas (modified after Strozyk et al., 2014). Major normal faults (offset < $100 \mathrm{~m}$ ) in the study area are marked.

The ZIIIAC stringer represents the base of the ZIII unit and consists of the gray Salt Clay, overlain by the $0.5-20 \mathrm{~m}$ thick Plattendolomit and the 15-130 m thick Hauptanhydrit (Van Gent et al., 2011). As the stringer is thick and encased in rock salt, it produces a high-amplitude reflection in the seismic data (Van Gent et al., 2011; Strozyk et al., 2012, 2014).

The ZIII and ZIV units above the stringer are compositionally and mechanically layered (Coelewij et al., 1978), and are traditionally subdivided into several subunits (Fig. 2b). The seismically transparent lower ZIII is 100 to $300 \mathrm{~m}$ thick. The ZIII-1 to -4 show a number of seismic reflections thought to reflect interbedding of halite with $\mathrm{K}-\mathrm{Mg}$ salt-rich layers 

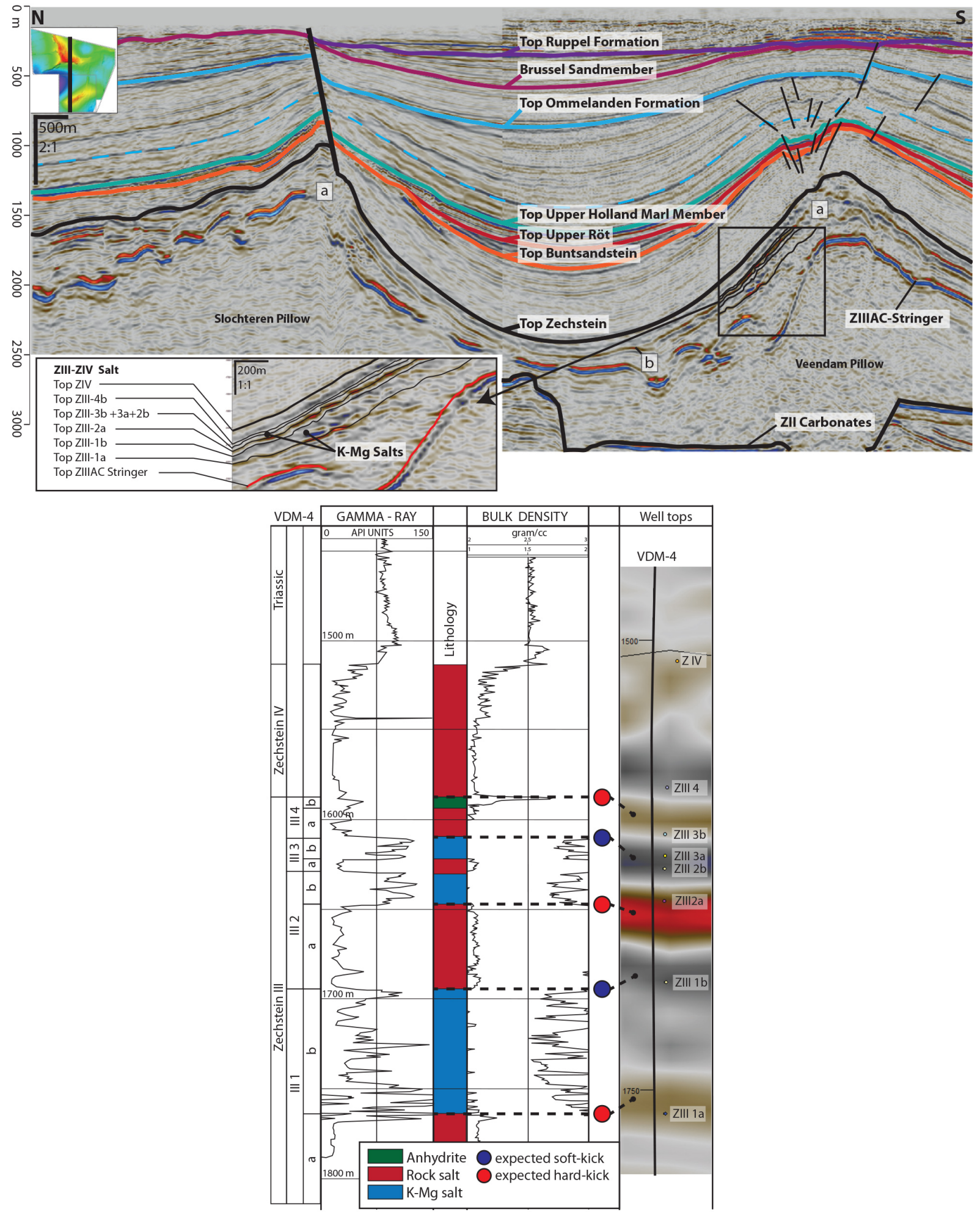

Figure 2. N-S profile through the study area with the Slochteren Pillow in the north (volume 2) and the Veendam Pillow in the south (volume 1). The black lines indicate a normal fault at the south margin of the Slochteren Pillow and smaller faults above the Veendam Pillow forming a crestal collapse graben. The basin between the pillows shows significant thickening of most layers. The Z3 stringer is separated under the basin and folded and thrusted in the pillows. Bottom: detailed view of the salt layers in the top of the salt bodies. (a) Decline of seismic quality in the pillow crest. (b) Merging of reflections under the basin. VDM-4 Well-log and expected seismic response compared to the real seismic response. 

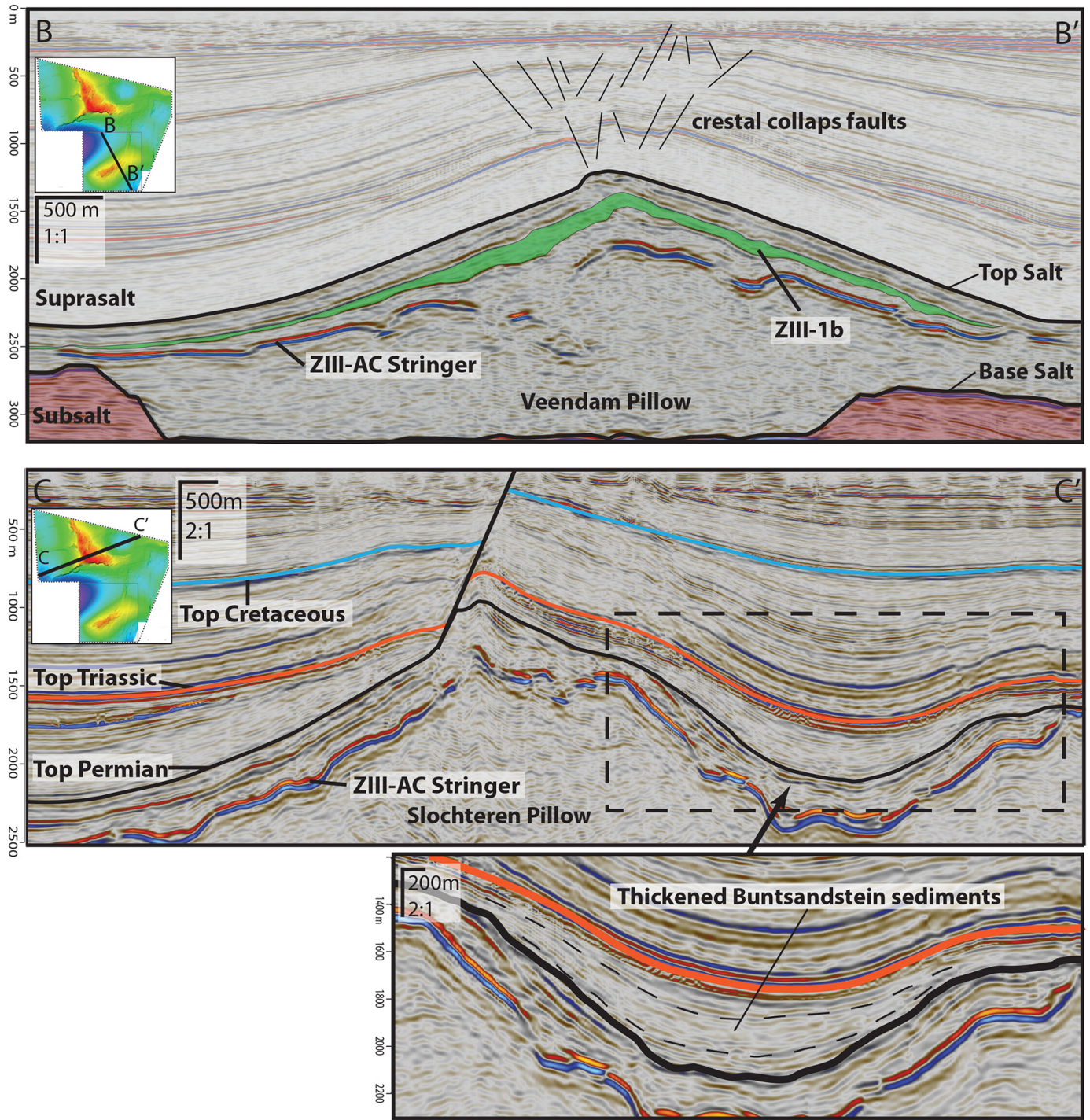

Figure 3. Top: NWN-SES profile through the Veendam Pillow showing thickening of the ZIII-1b (green) above the AC-stringer synclines and crestal collapse grabens above the pillow. Bottom: ESE-WNW profile through the Slochteren Pillow. Enhanced area is showing thickening of the Triassic towards the basin center.

in the ZIII- $1 b,-2 b$ and $-3 b$. Besides halite, the most common minerals here are carnallite, kieserite, and anhydrite, whereas in ZIII-1b bischofite is also present (Coelewij et al., 1978). Drill cores in the study area were used to differentiate varying evaporation conditions for the ZIII-1b compared to the ZIII-2b and 3b (Coelewij et al., 1978). ZIII-1b shows numerous alterations of bischofite, carnallite and halite as result of a regularly reversed evaporation process caused by intermittent influx of fresh seawater with a subsequent drop in salinity. The results are thin layers composed of one or two minerals such as halite, kieserite, which is indicative of shallow water co-precipitation (Coelewij et al., 1978). In ZIII$2 \mathrm{~b}$ and $-3 \mathrm{~b}$, indistinct bedding and weak development of cycles with intimate mixing of carnallite and halite crystals is thought to be the result of co-precipitation. Co-precipitation was interpreted to be caused by concentration stratification and simultaneous precipitation in two brine layers (Coelewij et al., 1978). The halite forms in the higher, less concentrated stratum, while the carnallite forms in the lower, higherconcentration/density stratum (Coelewij et al., 1978). This means that the water column during the ZIII- $2 \mathrm{~b}$ and $3 \mathrm{~b}$ precipitation was higher than during the ZIII- $1 \mathrm{~b}$ precipitation. Coelewij et al. (1978) used seismic acoustic impedance (AI) to evaluate the K-Mg grade of the layer. The percentage of carnallite and bischofite in a layer was interpreted to be inversely proportional to the $\mathrm{AI}$ and only disturbed by the high AI of kieserite.

The Zechstein is overlain by Triassic (Buntsandstein and upper Röt), Cretaceous (Rijnland and Chalk) the Tertiary units (Lower/Middle and Upper North Sea Group) and the 


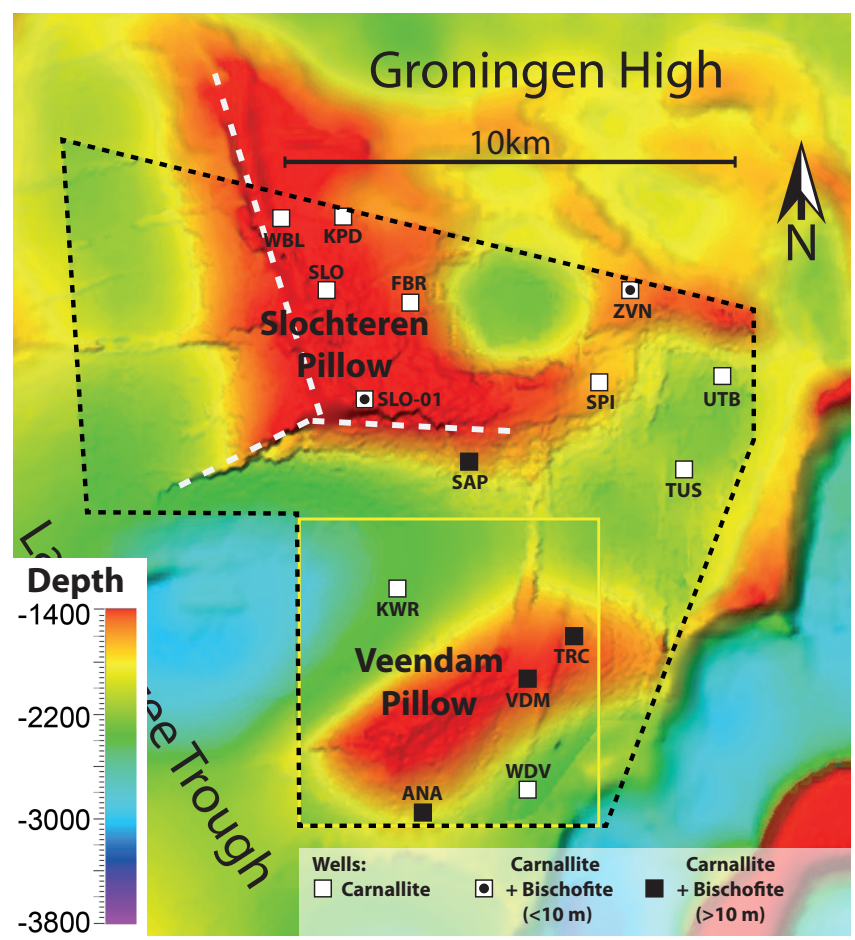

Figure 4. Top Salt surface map compiled after Strozyk et al. (2014) and this study, with well head locations. White dotted lines indicate major suprasalt faults at the Slochteren Pillow. The black dashed box indicates the study area and the yellow box indicates the location of seismic volume 1 .

Quaternary. The Jurassic is not present in the study area (Wong, 2007a).

\section{Data and methods}

We used two PSDM (pre-stack depth migrated) 3-D seismic volumes of different sizes and ages, provided by Nederlandse Aardolie Maatschappij (NAM). The southern seismic volume of $46 \mathrm{~km}^{2}$ mainly covers the Veendam Pillow and images down to $3.25 \mathrm{~km}$ depth. The northern volume covers $135 \mathrm{~km}^{2}$ and images down to $2.5 \mathrm{~km}$ depth (Figs. 2 and 4). Both seismic volumes overlap by $30 \mathrm{~km}^{2}$ and display vertical offsets between reflections due to differences in the velocity model during data processing. This offset is, however, less than $30 \mathrm{~m}$.

Furthermore, over 100 wells and side-tracks from 15 well locations were provided by NEDMAG and are taken from the publicly available TNO database. The included well tops and well $\log$ data were mainly used for well-to-seismic tie. Stratigraphic boundaries of the upper Zechstein cycles (ZIII1 to ZIV) were identified from existing well top information or were interpreted from well logs (GR, DEN). Interpreted log data showing the lithological composition was available for wells TRC-1 to -9 (TRC $=$ Tripscompagnie) and VDM1 to $-4(\mathrm{VDM}=$ Veendam $)$. Most wells were drilled into the
Rotliegend penetrating the entire Zechstein salt, except the TRC and VDM wells, which terminate in the ZIII-1a.

Based on the well-to-seismic tie 15, Zechstein seismic horizons were interpreted using Schlumberger's Petrel. Horizons were picked by a combination of manual and automated methods based on the continuity and connectivity of reflections. The interpreted horizons are Base Salt (= Top ZII-A), Top ZIII-AC ("stringer"), Top ZIII-1a, Top ZIII-1b, Top ZIII2a, Top ZIII-2b+ ZIII-3a + ZIII-3b, Top ZEIII-4b and Top Salt (Top ZIV; Fig. 2a and b). Layers ZIII-2b to ZIII-4b are not resolved in the seismic volume 2 .

Major stratigraphic units in the Zechstein's overburden were interpreted to help us reconstruct the study areas salt tectonic evolution: (i) Top Buntsandstein (Triassic), (ii) Top Upper Röt (Triassic), (iii) Top Upper Marl Member (Cretaceous), (iv) Top Chalk (Cretaceous), (v) Top Mid Brussels Sand Member (Tertiary), and (vi) Top Rupel Formation (Tertiary). Additionally, one intermediate reflection within the Chalk was interpreted (Figs. 2a and 5a). Stratigraphic thickness maps were calculated to identify sediment thickness changes. These changes were used to identify the timing and special variations in subsidence and uplift. The thinning of sediments above salt highs is used to identify reduced or non-deposition, or even uplift and erosion.

\section{Results}

\subsection{Structural overview of the study area}

The Rotliegend is crosscut by mainly E-W and N-S to NNW-SSE striking normal and occasionally strike-slip faults (Fig. 1). The faults generally have offsets smaller than $100 \mathrm{~m}$, with two larger, E-W striking normal faults bounding a $400 \mathrm{~m}$ deep graben below the Veendam Pillow (Figs. 1 and 6).

Two salt pillows are identified in the study area, the Veendam (cf. Coelewij et al., 1978) and Slochteren pillows (Fig. 4), which are surrounded by salt withdrawal basins filled by up to $3 \mathrm{~km}$ of post-salt strata (Fig. 4). Post-salt sediments are generally thicker in the basins and thinner above the salt pillows (Fig. 5). The Veendam Pillow strikes SW-NE and is $10 \mathrm{~km}$ long in the NE-SW direction and $5 \mathrm{~km}$ wide. The Zechstein is $2600 \mathrm{~m}$ thick in the pillow core, and the top of the pillow is at $1100 \mathrm{~m}$ depth. The Slochteren Pillow extends $10 \mathrm{~km}$ in the E-W and $14 \mathrm{~km}$ in the N-S direction. The Zechstein is of $1800 \mathrm{~m}$ thick in the pillow core and the top of the pillow is $1000 \mathrm{~m}$ below the surface. The overburden of the Slochteren pillow is deformed by a large, N-S striking fault and a smaller E-W striking fault are located on its eastern and southern flank (Figs. 1 and 6).

The Top Salt surface of the two pillows is generally smooth, locally offset by faults in the post-salt sediments. These faults can be divided into two groups: (1) normal faults with small offsets $(<100 \mathrm{~m})$ forming grabens above the pillows (Fig. 2a right side, Fig. 3 top), and (2) normal faults 

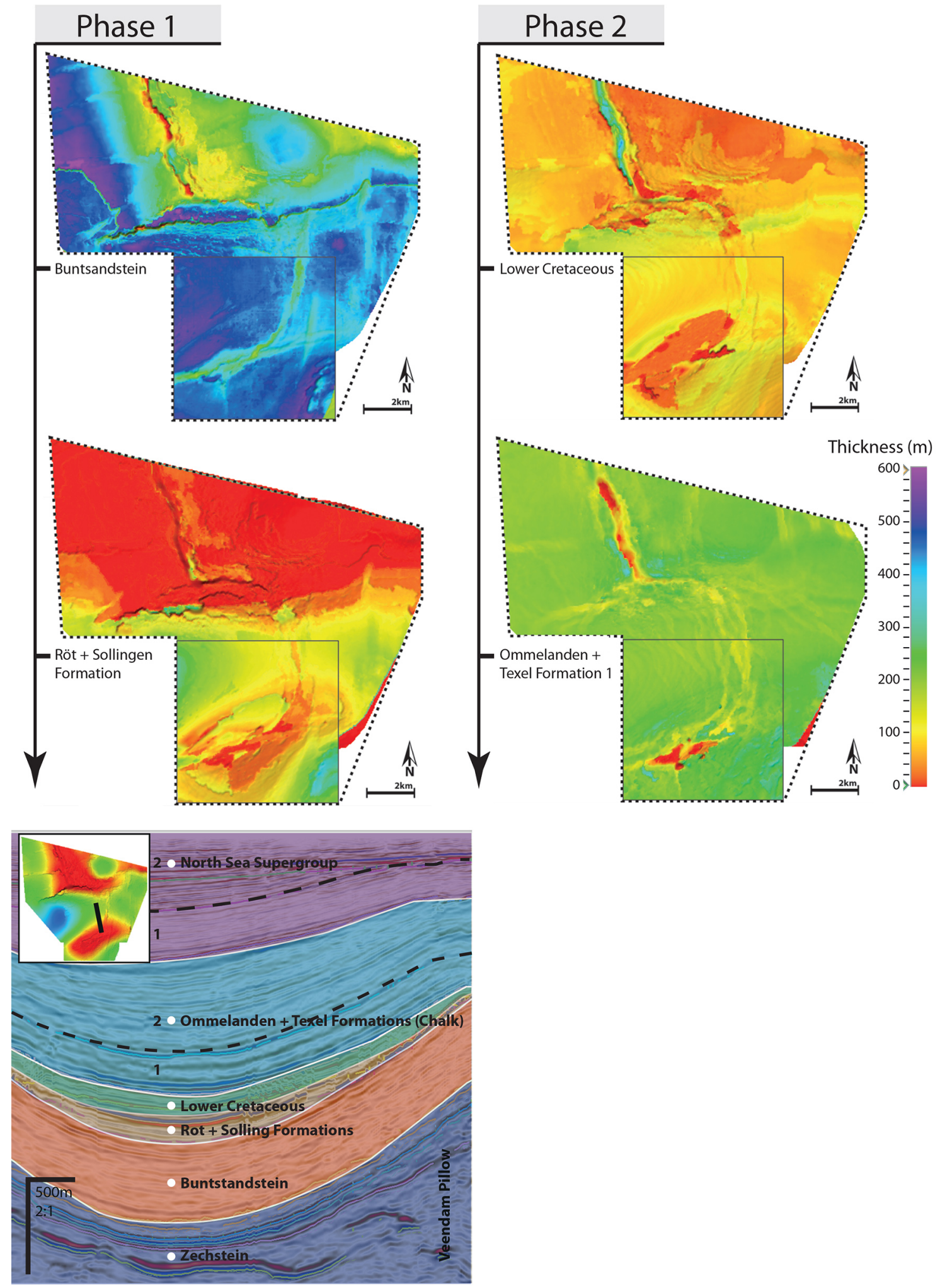

Figure 5. 


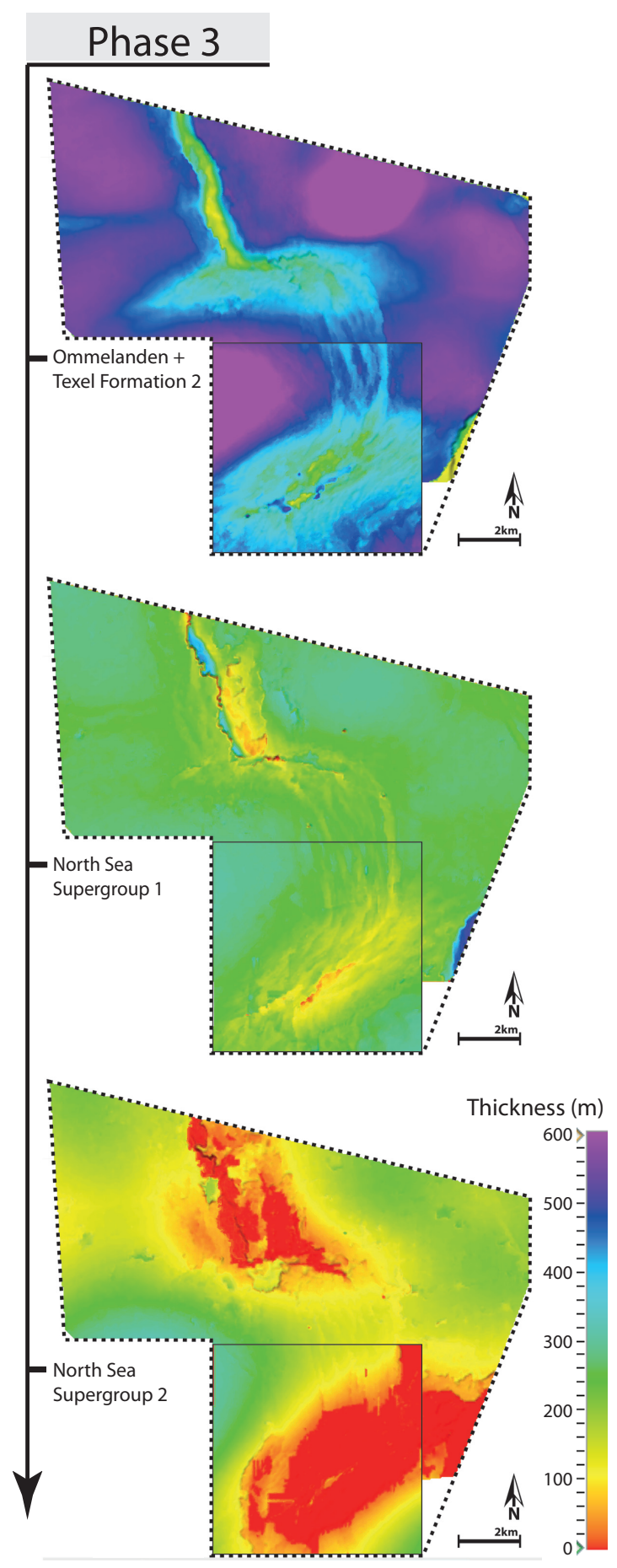

Figure 5. Supersalt thickness maps of the units mark in the profile at the bottom. Due to the influence of faults in the supersalt the thickness information in the center of the pillows is faulty. The dotted line in the chalk indicates the change from phase 2 to phase 3 (Fig. 5b). The thickness maps show substantial thickening above the basins in phase 1 and 3 (Fig. 5b) and constant thicknesses in phase 2 . with throws that can be traced from Top Salt up to the MidTertiary (Fig. 2 left side, Fig. 3 bottom), offsetting the postsalt sediments by up to 350 and $200 \mathrm{~m}$ for the N-S and E-W trending faults, respectively. The smaller normal faults are associated with elongated anticlines in the Top Salt surface (Figs. 3 and 6a), these anticlines are up to $500 \mathrm{~m}$ wide and up to $100 \mathrm{~m}$ high, showing classic reactive piercement geometries (Hudec and Jackson, 2007). The crest of the Slochteren Pillow is dominated by bigger faults (Fig. 2 and 3), but lacks the anticline at top salt.

\subsection{Stratigraphic units}

\subsubsection{ZIII-AC stringer}

The fragmented ZIII stringer has an average thickness of $40 \mathrm{~m}$. Below salt withdrawal basins the stringer is rather flat and parallel to Top Salt, while it shows complex patterns of rupture folding and tectonic duplication in the pillows. Fold axes have a wide range of strikes, and are often curved in harmony with Top Salt (Fig. 7). N-S and ENE-WSW striking folds are more common in the Veendam Pillow, whereas E-W and NNW-SSE striking folds occur in the Slochteren Pillow. Fold amplitudes are mostly $<100 \mathrm{~m}$, reaching up to $300 \mathrm{~m}$ in the northern flank of the Veendam Pillow. Stringer fragments that overlap a few tens of meters as well as a complex pattern of gaps are observed. In the Veendam pillow, the largest NE-SW striking gaps occur on the NW-flank of the pillow, whereas gaps in the center of the Slochteren pillow gaps define an almost polygonal pattern (Fig. 7).

\subsubsection{ZIII-1 to IV}

The ZIII-1a, -2a, and -3a halite layers represent are inferred to relatively strong units, whereas the K-Mg salt-rich ZIII- $1 b,-2 b$ and $-3 b$ layers are interpreted to be relatively weak (Fig. 2b). The reflectors, representing the boundaries between these units are mostly continuous, with two exceptions: (i) reflection continuity and amplitudes decrease strongly towards the tops of salt pillows (i.e., reflections cannot be traced in the Veendam Pillow crest, show several gaps in the Slochteren crest, and are not visible below suprasalt faults at the Slochteren Pillow; Fig. 2a), and (ii) under sedimentary basins the top ZIII-1a and Top ZIII-2a reflections merge, and Top ZIII-1b becomes invisible (Fig. 2a). The top ZIII-1b to -3b reflectors principally follow Top Salt, and the units in between thicken towards the pillows' crests. In general, the thickness variation of $<30 \mathrm{~m}$ to ca. $400 \mathrm{~m}$ in the K$\mathrm{Mg}$ salt-bearing ZIII-1b is much larger than in other units and partially correlates with the stringer geometry (Figs. 6d and 7). More specifically, the ZIII-1b is thicker above stringer fold synclines than above fold anticlines. The ZIII-1b thickness reaches its maximum (Fig. 6d) above the deep stringer anticline at the northwestern flank of the Veendam Pillow (Fig. 7, profile B). In addition, ZIII-1b is thicker directly be- 


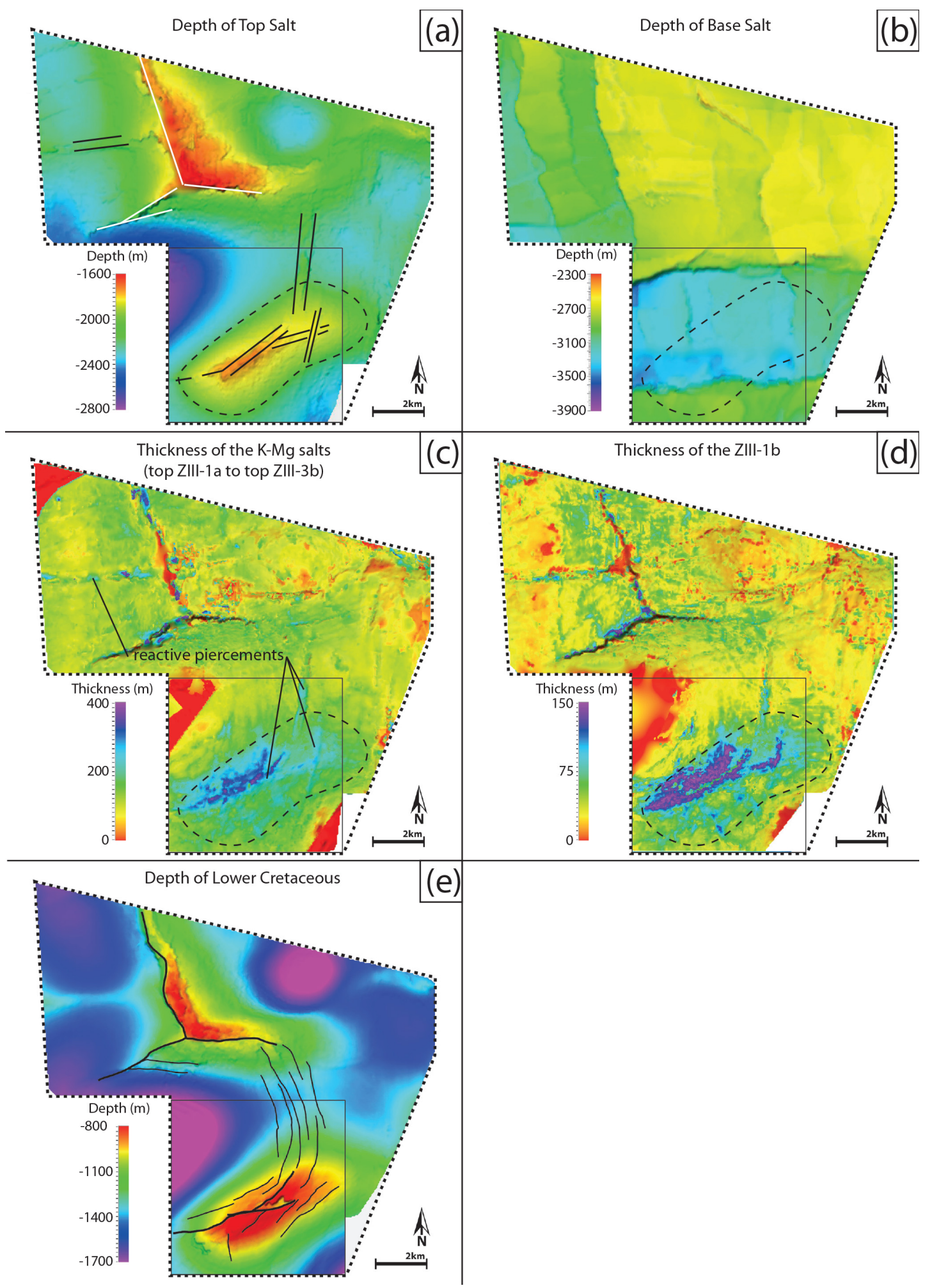

Figure 6. Detailed Top Salt map (black box indicates location of seismic volume 1) with surface inquiries (black lines) as a result of crestal collapses above salt pillows. The white lines indicate faults offsetting the Top Salt contact at the Slochteren Pillow. Thickness maps of top ZIII-1a to top ZIII-3b and top ZIII-1a to top ZIII-1b and a detailed map of the Subsalt surface (modified after Strozyk, 2014). Layers show significant thickening to the crest and under crestal collapse structures. The thickest parts are not in the middle of the crest (Veendam Pillow marked by dashed line) but on the NW flank of the Veendam Pillow towards the center of the Base Salt graben. On the depth map of the Lower Cretaceous faults offsetting the layer are marked in black. 


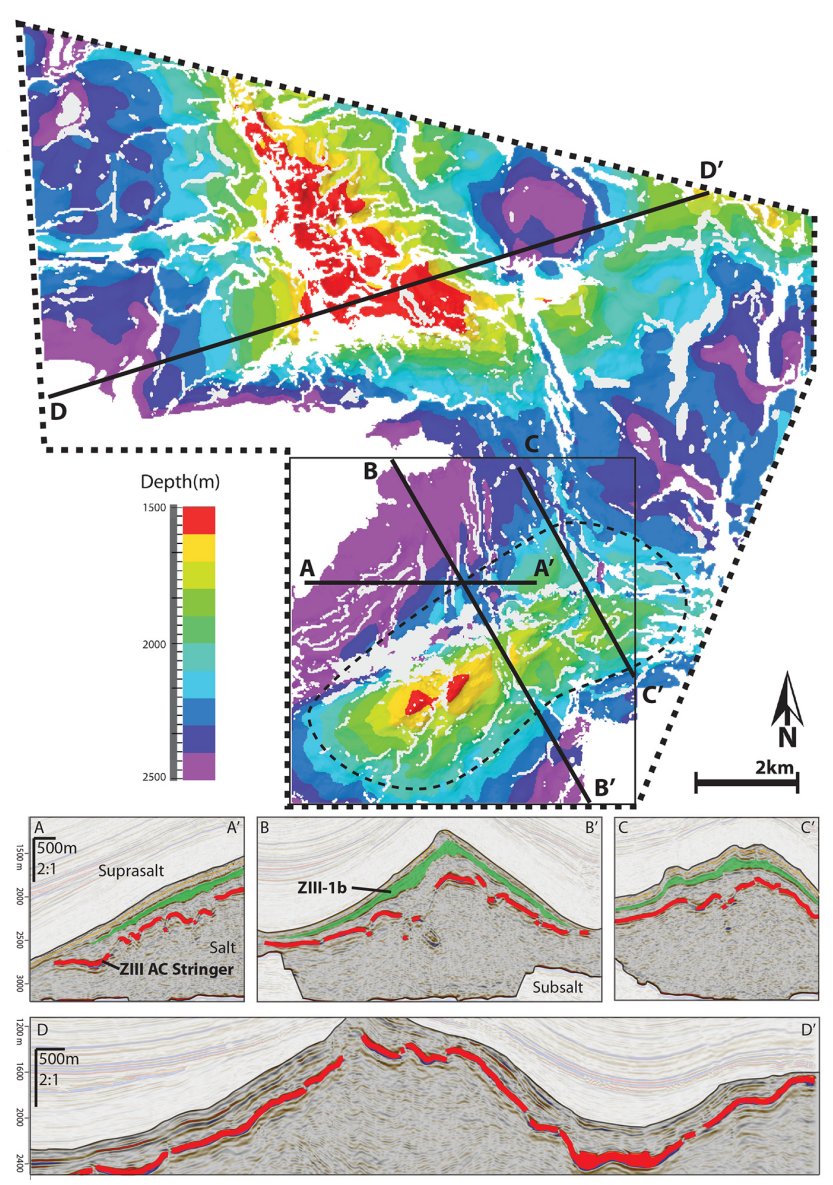

Figure 7. Map view of the ZIII stringer showing the different rupture patterns in the two pillows with several profiles. The Veendam Pillow is outlined with the black dashed line.

low the small anticlines of Top Salt (see section: Discussion, Phase 3). The ZIV generally marks Top Salt, except in parts of the Slochteren Pillow, where this unit is absent.

\subsubsection{Postsalt}

The Lower Triassic Buntsandstein sediments represent the oldest Postsalt sediments above the salt with an average thickness of ca. $100 \mathrm{~m}$ above the Slochteren Pillow. Above the Veendam Pillow the Buntsandstein is around $400 \mathrm{~m}$ thick, in the surrounding basins the unit is up to $550 \mathrm{~m}$ thick (Fig. 5). Above the Top Salt anticlines (see section: Discussion, Phase1; Fig. 6) the Buntsandstein can be as little as $200 \mathrm{~m}$ thick. Adjacent to the anticlines it shows a minimum thickness of $400 \mathrm{~m}$ at the western flank of the Veendam Pillow (Fig. 5). Top Bundsandstein has a conformable upper contact with the Upper Triassic Upper Röt Formation, whereas it has an erosional contact with the Upper Marl Member in the northern part of the study area (Fig. 2a), where the Upper Röt is missing (Fig. 5).
The Upper Triassic Upper Röt and Solling formations together have an average thickness of $200-300 \mathrm{~m}$ in the salt withdrawal basins, whereas it is significantly thinner above the Veendam Pillow (Fig. 5). This unit is not present above the Slochteren Pillow (Fig. 5).

The Cretaceous Upper Marl Member varies in thickness from 50 to $140 \mathrm{~m}$. In contrast to the underlying units, it is not preferentially thicker in the basins (Fig. 5). The unit's upper and lower contacts are mostly concordant (Figs. 2 and 3).

The Cretaceous Chalk is 300 to $850 \mathrm{~m}$ thick and is divided into two seismically different subunits. The lower subunit shows no significant change in thickness across the study area (Fig. 5), while the upper subunit is thicker in the salt withdrawal basins and is truncated at its top by the Base Tertiary (Figs. 2 and 3).

The Mid Brussels Sand Member of the Tertiary North Sea Supergroup shows a thickness of $100 \mathrm{~m}$ above the pillows, which increases up to $270 \mathrm{~m}$ in the flanking basins (Fig. 5). The unit's top is mostly concordant to overlying strata. An exception can be observed at the Slochteren Pillow where thinning and toplaps in footwall position of the supra salt truncating faults are visible (Figs. 2 and 3).

The Rupel Formation of the Tertiary North Sea Supergroup is thick in the basins and significantly thins and terminates towards the salt pillows, (Fig. 5). Younger sediments are not or are only partly resolved in the seismic data and were thus not interpreted.

\subsection{ZIII K-Mg salts in well data}

\section{Bischofite}

Well data show abundant bischofite in the southern part of the study area (Fig. 4). Highest concentrations were identified in TRC wells on the eastern flank of the Veendam Pillow, where bischofite shows a cumulative thickness of up to $58 \mathrm{~m}$. Significant cumulative bischofite thicknesses (i.e., $>10 \mathrm{~m}$ ) are also present in the VDM wells, the AnnerveenAnlo (ANA -01) well at the south flank of the Veendam Pillow, and the Sappemeer (SAP) wells on the southeastern flank of the Slochteren Pillow. Furthermore, bischofite is present with $5 \mathrm{~m}$ cumulative thickness in a Slochteren (SLO$01)$ well in the crest of the Slochteren Pillow and in the Zuiderveen (ZVN-01) well (i.e., $6 \mathrm{~m})$ in a small salt high at the northeastern boundary of the study area. Wells on the Slochteren Pillow north of SLO-01 (i.e., Froombosch (FBR), Kooipolder (KPD) and Woudbloem; WBL) show no significant bischofite occurrences. Also, no bischofite is present in the basins east of the Slochteren Pillow at Spitsbergen (SPI), Tusschenklappen (TUS) and Uiterburen (UTB), in the basin west between the two pillows at Kiel-Windeweer (KWR), and south of the Veendam Pillow at Annerveen-Wildervank (WDV). 


\section{Carnallite}

Carnallite is present in all wells in the study area. Cumulative thicknesses are generally higher in the pillows than in the basins. The highest concentrations of 70 to $136 \mathrm{~m}$ cumulative thickness are found in the southern part of the study area in TRC and VDM wells in the Veendam Pillow. South of this, thicknesses of 30 to $65 \mathrm{~m}$ occur. In the Slochteren Pillow, around $50 \mathrm{~m}$ cumulative thickness was identified in SLO, FRB, KPD, and SAP. In the basins east of the pillow, only 10 to $30 \mathrm{~m}$ cumulative carnallite thicknesses are present in the TUS and UTB wells.

\section{Discussion}

\subsection{Sedimentary architecture and K-Mg salt deposition}

As the K-Mg salt layers have a much lower viscosity than the halite, there is the potential for high strains in these layers. Therefore, the observed spatial variation in thickness can be either sedimentary or tectonic in origin and different for the carnallite and bischofite layers.

To allow for precipitation of a fully developed evaporitic cycle, including the deposition of significant amounts of bischofite, a pond-like morphological depression and prolonged arid conditions without seawater refreshing events is required. This could have been the case above the basement graben below the study area, where subsalt faulting may have produced gentle depressions in the evolving evaporites. Recent studies show that at least some subsalt faults in the study area were active during ZII and ZIII precipitation (Biehl et al., 2014; Strozyk et al., 2014), providing support for this hypothesis. Mg-enriched residual brines are interpreted to have collected inside the depression of the carnallite-rich ZIII$1 \mathrm{~b}$ layers above the basement graben, in the area where the Veendam Pillow later formed, with bischofite precipitation in local lenses (Fig. 8a). Smaller bischofite occurrences in other parts of the study area suggest the presence of several smaller ponds, or that later strains squeezed parts of the bischofite deposit towards some distal areas. Unlike the bischofite, carnallite was deposited regionally as continuous layers of varying thickness across the entire study area.

\subsection{Salt tectonic evolution}

To analyze the relative salt movements in the study area we consider the spatial and temporal changes in postsalt sediment thickness and the associated withdrawal and accumulation of salt pillows with thinning of sediments above. The resulting history of salt-tectonics can be summarized in three main phases (Fig. 5):

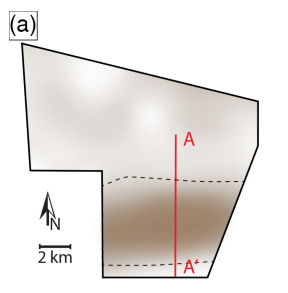

Initial sedimentary architecture
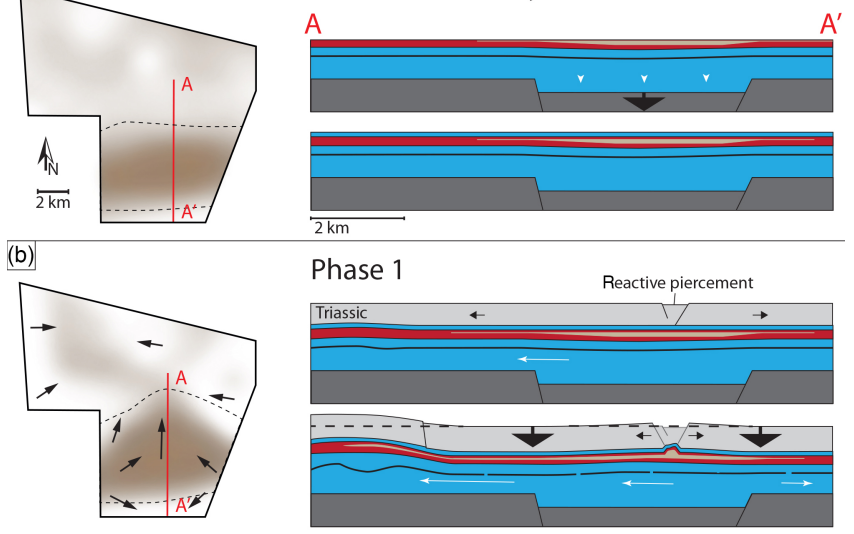

Phase $1 \quad$ Reactive piercement
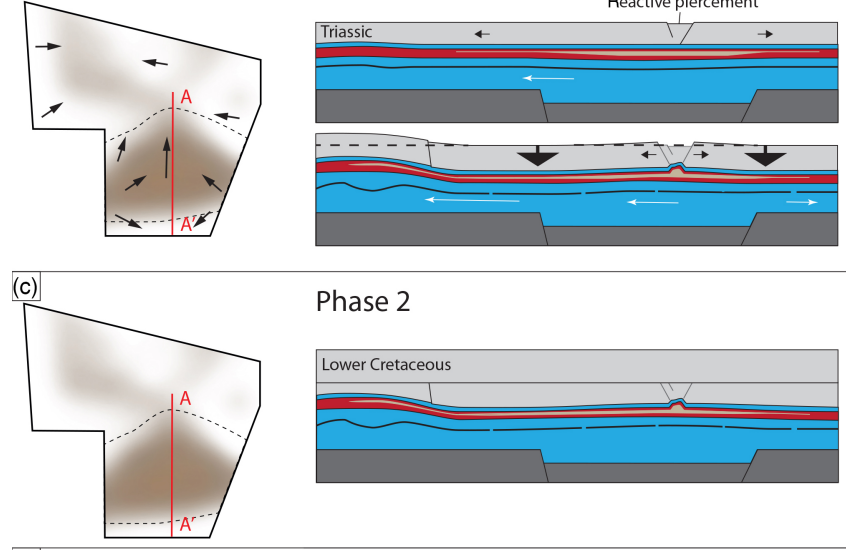

Phase 2

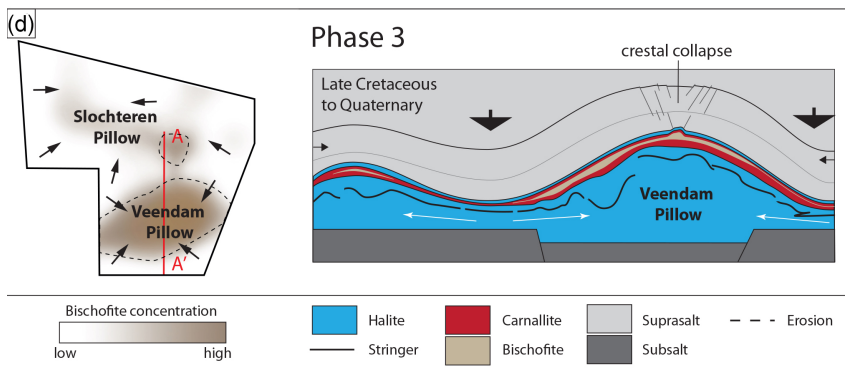

Figure 8. Conceptual sketch (depth not to scale) of salt deformation in the study area: maps on the left indicate movements in the bischofite deposit; the profile sketches on the right side indicate corresponding deformation of the Zechstein (incl. ZIII AC stringer and $\mathrm{K}-\mathrm{Mg}$ salts) and the suprasalt sediments. Black arrows indicate movements in the suprasalt sediments (e.g., extension and subsidence), white lines movements in the salt (e.g. salt withdrawal below sediment basins): (a) tectonic movements in the subsalt allow for localized bischofite deposition in the area of the later Veendam Pillow; (b) differential loading and extension in the Triassic sediments and during Jurassic erosion cause salt withdrawal and boudinage of the ZIII stringer in the area of the later Veendam Pillow, while salt accumulation and doming farther north triggers the formation of the Slochteren Pillow; K-Mg salts are initially deformed by extensional features in the salt's overburden; (c) no deformation during stable phase 2; (d) ongoing subsidence and salt withdrawal below sedimentary basins cause the formation of the Veendam Pillow and further grow of the Slochteren Pillow. The bischofite deposits are dragged into the Veendam Pillow, where they deform due to ZIII stringer deformation and structures in the supra-salt. 


\section{Phase 1}

During the Triassic, localized differential loading by the early postsalt sediments induced salt withdrawal below the Veendam area, while salt flowed towards the area of the later Slochteren pillow, as indicated by strong variations in Buntsandstein thickness (Fig. 8). Regional extension during the Triassic (Mohr et al., 2005; Geluk, 2007a; Vackiner et al., 2011) was described to cause faulting and rafting of the Triassic sediments. Thickening of Buntsandstein towards the basin center in the north (Fig. 3 bottom) indicates that salt movements occurred in the study area in this time. However, the rather tabular Buntsandstein geometries in the southern and western study area indicate that large areas were not affected by early differential loading and salt flow, and that most of the salt deformation took place later in the Late Triassic and Jurassic. The significantly thinner (i.e., $100 \mathrm{~m}$ ) Triassic sediments above the Slochteren Pillow are therefore the result of erosion of a tabular sediment layer that was truncated during the Jurassic hiatus. We infer that salt withdrawn from beneath the subsiding basins flowed mainly from the south and the east towards the Slochteren Pillow and also into the much more slowly inflating Veendam Pillow. Absence of Upper Röt sediments above the Slochteren Pillow indicates that, during the Late Triassic the pillow continued to rise. At the same time, reactive piercement structures in Triassic sediments above the Veendam Pillow evolved and formed smallscale Top Salt anticlines. These reactive piercement structures caused by regional extension fit into the rafting tectonics described by literature (Mohr et al., 2005; Vackiner et al., 2011).

\section{Phase 2}

The Jurassic is absent (cf. Wong et al., 2007a), whereas the Lower Cretaceous interval is 50 to $140 \mathrm{~m}$ thick and does not thicken into the salt withdrawal basins. The layer has a rather continuous thickness compared to the surrounding units in the study area. Constant sediment thicknesses in the lower part of the overlying Chalk is another sign that the salt movement was very slow.

\section{Phase 3}

Significant thickening of upper Chalk sediments into the salt withdrawal basins indicates renewed salt flow into the Veendam and the Slochteren pillows (Fig. 8), caused by regional compression during the Late Cretaceous inversion (Wong, 2007b). The regional compressional buckling of the postsalt sediments led to salt rising together with local extensional bending in the sediments above the salt pillows and produced crestal collapses (cf. Mohr et al., 2005).

Salt tectonics continued during the Tertiary, but slowed during the deposition of the Lower North Sea Group. During deposition of the Middle and upper North Sea Group, faults above the Slochteren Pillow offsetting Top Salt were active (Figs. 2 and 3). The N-S striking and the E-W striking fault are both parallel to faults in the Base Salt at the Slochteren pillow and offset into the hanging walls. Post-Tertiary sediments are significantly thicker in the basins than above the pillows indicating ongoing salt movement into the Quaternary.

\subsection{Evolution of the internal structure of the salt}

In addition to the location of the bischofite layers above the subsalt graben, the second argument for a locally confined carnallite-bischofite lens is the deformation history. If the original bischofite layer had been continuous over the study area, the first stage of deformation would have removed it from the area of the future Veendam pillow, and enriched it in the incipient Slochteren Pillow, which is not the case.

Coelewij et al. (1978) suggests that truncation of a salt body in contact with groundwater could lead to a loss of the highly soluble bischofite. However, the bischofite-rich ZIII1b layer does not thin towards the faults offsetting the Top Salt in Slochteren (Figs. 2a and 3). Furthermore, it is more likely that only thin layers of bischofite were deposited here in the first place (Fig. 8). The up to $36 \mathrm{~m}$ thick bischofite encountered in the SAP wells, which are located on the southeastern flank of the Slochteren Pillow, are interpreted as local fold hinge or boudin-neck (Fig. 8).

Coelewij et al. (1978) suggested that the thick bischofite occurrences were caused by thickening in the fold hinges. From our thickness maps (Fig. 6c and d) however it is clear that the ZIII-1b layer's thickness does not conform to the salt pillow (Fig. 6a), it is rather located on the NW flank. This argues against redistribution at the scale of the pillow. An alternative explanation is related to the structural evolution of the anhydrite-carbonate stringer located deeper in the structure (Fig. 7).

A closer look at the rupture patterns of the stringer shows a strikingly different pattern in the Veendam and the Slochteren pillows (Fig. 7). In the Slochteren Pillow, the rupture pattern is consistent with stretching of the layer during the rise of the pillow (Abe et al., 2013), with two major boudin zones parallel to the crest, and smaller polygonal fractures in the crestal zone. In the Veendam Pillow, however, the largest ruptures are clearly off from the crest of the structure (Fig. 6d). To explain these, we recall that the initial phase of salt flow was withdrawal from the Veendam area, which has led to boudinage and rupture of the stringer before the start of growth of the Veendam pillow (Fig. 8b).

The presence of the broken stringer fragments at the start of pillow growth is interpreted to have made the internal deformation of the Veendam pillow more heterogeneous. This led to the nucleation of smaller scale (few $100 \mathrm{~m}$ ) folds in the surrounding halite, which in turn formed saddle reef structures where the bischofite was tectonically thickened (Fig. 7, profiles). During salt flow from the location of the later Veen- 
dam Pillow towards the Slochteren Pillow the ZIII stringer is dragged with the salt and boudinaged. Later, the salt flowed from the subsiding basins also into the Veendam Pillow. The ZIII stringer was dragged with the salt, which locally led to compression structures like folds and thrusts (Fig. 8d). This deformation localized flows in the overlaying mobile $\mathrm{K}-\mathrm{Mg}$ salts to significantly thicken above stringer synclines.

A secondary effect of the extension during Late Triassic and the formation of reactive piercements is flow in topmost salts that were dragged into the bottom of these structures. We propose that especially the highly mobile $\mathrm{K}-\mathrm{Mg}$ salts filled the space formed by the faulted sediments above Top Salt.

While all these processes may affect the entire salt section, the low viscosity of the $\mathrm{K}-\mathrm{Mg}$-rich salts strongly amplifies these effects.

On a large scale, $\mathrm{K}-\mathrm{Mg}$ salts are passively dragged with the general salt flows, and thus preferably occur inside salt highs. Here, their thickness further increases towards the crest, which results from radial salt flows towards the center of the salt high.

In addition, faulting in the salt's overburden may trigger the mobile $\mathrm{K}-\mathrm{Mg}$ salts to flow into the space created by the deformation of the overlying rocks.

$\mathrm{K}-\mathrm{Mg}$ salts can be highly influenced by deformation of high-viscosity layers in their vicinity (e.g., anhydrite and carbonates). Folding of the stringers may lead to strong thickness variations in the $\mathrm{K}-\mathrm{Mg}$ salts on local scale.

\section{Conclusions}

In the NE Netherlands, two Zechstein salt pillows show exceptional thickness of carnallite and bischofite in the uppermost salt section. Initial precipitation of bischofite in the area of the future Veendam Pillow occurred from Mg-rich residual brines concentrated in surface depressions above an active basement graben. The rock salt layers contain the much weaker carnallite and bischofite layers and the much stronger Zechstein III anhydrite-carbonate stringer, providing an example of extreme rheological heterogeneities in a salt structure.

During a first stage of salt tectonics differential loading by Triassic sediments induced salt withdrawal from the area of the future Veendam Pillow, which led to boudinage of the ZIII anhydrite-carbonate stringer while the K-Mg lens remained relatively undeformed. This was followed by two phases of pillow growth separated by limited salt flow during the Jurassic to mid Cretaceous. The $\mathrm{K}-\mathrm{Mg}$ salt layers were deformed with the evolving salt pillows. Deformation of K$\mathrm{Mg}$ salt-rich layers in the evolving salt pillows was strongly disharmonic and strongly influenced by folding of the underlying ruptured ZIII stringer. The second phase of pillow growth triggered crestal collapse above both salt anticlines and large-scale faulting above the Slochteren Pillow. The highly mobile $\mathrm{K}-\mathrm{Mg}$ salts were thickened in salt anticlines below the collapse structures.

Acknowledgements. The authors thank Nedmag Industries for the financial support and further thank NEDMAG and Nederlandse Aardolie Maatschappij (NAM) for providing the data. Schlumberger is thanked for providing Petrel seismic interpretation software under academic license. Furthermore, we are deeply grateful to the editors and reviewer Christopher Jackson as well as a second unknown reviewer for their many fruitful comments and suggestions that strongly improved our manuscript.

Edited by: F. Rossetti

\section{References}

Abe, S., Urai, J. L., and Kettermann, M.: Fracture patterns in nonplane strain boudinage-insights from 3-D discrete element models, J. Geophys. Res.-Sol. Ea., 118, 1304-1315, doi:10.1002/jgrb.50126, 2013.

Albertz, M. and Ings, S. J.: Some consequences of mechanical stratification in basin-scale numerical models of passive-margin salt tectonics, Geol. Soc. London, Spec. Publ. 363, 303-330, doi:10.1144/SP363.14, 2012.

Albertz, M., Beaumont, C., Shimeld, J. W., Ings, S. J., and Gradmann, S.: An investigation of salt tectonic structural styles in the Scotian Basin, offshore Atlantic Canada: 1. Comparison of observations with geometrically simple numerical models, Tectonics, 29, TC4017, doi:10.1029/2009TC002539, 2010.

Behlau, J. and Mingerzahn, G.: Geological and tectonic investigations in the former Morsleben salt mine (Germany) as a basis for the safety assessment of a radioactive waste repository, Eng. Geol., 61, 83-97, doi:10.1016/S0013-7952(01)00038-2, 2001.

Biehl, B. C., Reuning, L., Strozyk, F., and Kukla, P. A.: Origin and deformation of intra-salt sulphate layers: an example from the Dutch Zechstein (Late Permian), Int. J. Earth Sci. 103, 697-712, doi:10.1007/s00531-014-0999-4, 2014.

Borchert, H. and Muir, R.: Salt deposits: the origin, metamorphism and deformation of evaporites, D. Van Nostrand Company Ltd, London, 338 pp., 1964.

Bornemann, O. and Fischbeck, R.: Zur geologie des salzstocks Gorleben nach den Bohrergebnissen, Deutschland Bundesamt für Strahlenschutz, Salzgitter, 65 pp., 1991.

Bornemann, O., Behlau, J., Fischbeck, R., Hammer, J., Jaritz, W., Keller, S., Mingerzahn, G., and Schramm, M.: Projekt Gorleben, Standortbeschreibung Gorleben, Teil 3: Ergebnisse der über- und untertägigen Erkundung des Salinars, Geologisches Jahrbuch. Bundesanstalt für Geowissenschaften und Rohstoffe (BGR), Hannover, 211 pp., 2008.

Brun, J. P. and Mauduit, T. P. O.: Salt rollers: Structure and kinematics from analogue modelling, Mar. Pet. Geol., 26, 249-258, doi:10.1016/j.marpetgeo.2008.02.002, 2009.

Burliga, S.: Kinematics within the Klodawa salt diapir, central Poland, Geol. Soc. London, Spec. Publ., 100, 11-21, doi:10.1144/GSL.SP.1996.100.01.02, 1996.

Cartwright, J., Jackson, M. P. A., Dooley, T., and Higgins, S.: Strain partitioning in gravity-driven shortening of a thick, multilayered 
evaporite sequence, Geol. Soc. London, Spec. Publ. 363, 449470, doi:10.1144/SP363.21, 2012.

Cerqueira, R. M., Chaves, A. P. V., Pessoa, A. F. C., Monteiro, J. L. A., Pereira, J. C., and Wanderley, M. L.: Principais depositos minerais do Brasil, in: Rochas E Minerais Industriais, Pricipal Mineral Deposits of Brazil, v. 4, Industrial Rocks and Minerals ,Brasilia, Brazil Departamento Nacional de Producao Mineral, 277-312, 1997.

Chemia, Z., Koyi, H., and Schmeling, H.: Numerical modelling of rise and fall of a dense layer in salt diapirs, Geophys. J. Int., 172, 798-816, doi:10.1111/j.1365-246X.2007.03661.x, 2008.

Chemia, Z., Schmeling, H., and Koyi, H.: The effect of the salt viscosity on future evolution of the Gorleben salt diapir, Germany, Tectonophysics, 473, 446-456, doi:10.1016/j.tecto.2009.03.027, 2009.

Coelewij, P., Haug, G., and Van Kuijk, H.” Magnesium-salt exploration in the northeastern Netherlands, Geol. Mijnb., 57, 487502, 1978.

De Jager, J.: Geological development, in: Geology of the Netherlands, edited by: Wong, T. E., Batjes, D. A. J., and De Jager, J., Royal Netherlands Academy of Arts and Sciences, 5-26, 2007.

Dooley, T. P., Jackson, M. P. A., Jackson, C. A.-L., Hudec, M. R., and Rodriguez, C. R.: Enigmatic structures within salt walls of the Santos Basin - Part 2: Mechanical explanation from physical modeling, J. Struct. Geol., 75, 163-187, doi:10.1016/j.jsg.2015.01.009, 2015.

Fiduk, J. C. and Rowan, M. G.: Analysis of folding and deformation within layered evaporites in Blocks BM-S-8 \& -9, Santos Basin, Brazil. Geol. Soc. London, Spec. Publ., 363, 471-487, doi:10.1144/SP363.22, 2012.

Fokker, P. A.: The behaviour of salt and salt caverns, Dissertation, Delft University of Technology, 143 pp., 1995.

Gärtner, G., Stockmann, N., Fricke, H., and Wallmüller, R.: Geological characterization of the Asse salt mine for mining, disposal of radioactive waste, and proof of long-term safety, in: Reviews in Engineering Geology Volume XIX: Deep Geologic Repositories, 41-52, doi:10.1130/2008.4119(05), 2008.

Geluk, M. C.: Internal tectonics of salt structures, J. Seism. Explor., 7, 237-250, 1998.

Geluk, M. C.: Triassic, in: Geology of the Netherlands, edited by: Wong, T. E., Batjes, D. A. J., De Jager, J., Royal Netherlands Academy of Arts and Sciences, 85-106, 2007a.

Geluk, M. C.: Permian, in: Geology of the Netherlands, edited by: Wong, T. E., Batjes, D. A. J., and De Jager, J., Royal Netherlands Academy of Arts and Sciences, 63-83, 2007b.

Geluk, M. C., Paar, W. A., and Fokker, P. A.: Salt, in: Geology of the Netherlands, Wong, T. E., Batjes, D. A. J., and De Jager, J., Royal Netherlands Academy of Arts and Sciences, 283-294, 2007.

Geluk, M. C., Röhling, H., and Brückner-Röhling, S.: Salt occurrences in the Netherlands and Germany: new insights in the formation of salt basins, in: Proceedings of the 8th World Salt Symposium, edited by: Geertman, R. M., May 2000, The Hague, Elsevier, 126-131, 2000.

Goteti, R., Ings, S. J., and Beaumont, C.: Development of salt minibasins initiated by sedimentary topographic relief, Earth Planet. Sci. Lett., 339-340, 103-116, doi:10.1016/j.epsl.2012.04.045, 2012.

Hammer, J., Behlau, J., Mingerzahn, G., and Mertineit, M.: The mechanical behavior and geometry of anhydrite layers in rock salt: Observations from nature, in: Natural Analogues for Safety Cases of Repositories in Rock Salt - "Salt Club" Workshop Proceedings Braunschweig, Germany, 05-07 September 2012, Hosted by Gesellschaft Für Anlagen Und Reaktorsicherheit (GRS) mbH, Braunschweig and Project Management Agency, 2014.

Hudec, M. R. and Jackson, M. P. A.: Terra infirma: Understanding salt tectonics, Earth-Science Rev., 82, 1-28, doi:10.1016/j.earscirev.2007.01.001, 2007.

Jackson, C. A.-L., Jackson, M. P. A., Hudec, M. R., and Rodriguez, C.: Internal structure, kinematics, and growth of a salt wall: Insights from 3-D seismic data, Geology, 42, 307-310, doi:10.1130/G34865.1, 2014.

Jackson, C. A.-L., Jackson, M. P. A., Hudec, M. R., and Rodriguez, C. R.: Enigmatic structures within salt walls of the Santos Basin - Part 1: Geometry and kinematics from 3-D seismic reflection and well data, J. Struct. Geol., 75, 135-162, doi:10.1016/j.jsg.2015.01.010, 2015.

Jackson, M. P. A. and Talbot, C. J.: External shapes, strain rates, and dynamics of salt structures, Geol. Soc. Am. Bull. 97, 305-323, doi:10.1130/0016-710.1130/00167606(1986)97<305:ESSRAD> 2.0.CO;2, 1986.

Jackson, M. P. A. and Talbot, C.: Anatomy of mushroomshaped diapirs, J. Struct. Geol., 11, 211-230, doi:10.1016/01918141(89)90044-8, 1989.

Jackson, M. P. A., Cornelius, R. R., Craig, C. H., Gansser, A., Stöcklin, J., and Talbot, C. J.: Salt Diapirs of the Great Kavir, Central Iran, Memoir of the Geological Society of America, doi:10.1130/MEM177, 1990.

Jackson, M. P. A., Roberts, D., and Snelson, S.: Salt Tectonics: A Global Perspective: Based on the Hedberg International Research Conference, Bath, UK, September 1993, No. 65, Amer Assn of Petroleum Geologists, Tulsa, Oklahoma, 467 pp., 1996.

Koyi, H. A.: Modeling the influence of sinking anhydrite blocks on salt diapirs targeted for hazardous waste disposal, Geology, 29, 387-390, doi:10.1130/00917613(2001)029<0387:MTIOSA> 2.0.CO;2, 2001.

Kukla, P., Pechnig, R., and Urai, J.: Analysis and evaluation of the Gorleben site characteristics, Report on the working package 2, Preliminary safety analysis Gorleben, Gesellschaft fuer Anlagenund Reaktorsicherheit mbH (GRS), Koeln (Germany), Funding organisation: Bundesministerium fuer Umwelt, Naturschutz und Reaktorsicherheit, Berlin (Germany), ISBN 978-3-939355-52-6, 2011.

Langbein, R.: The Zechstein sulphates: The state of the art, in: The Zechstein Facies in Europe, edited by: Peryt, T. M., Lecture Notes in Earth Science, Vol. 10, Springer- Verlag Berlin, Heidelberg, 143-188, 1987.

Li, S., Abe, S., Reuning, L., Becker, S., Urai, J. L., and Kukla, P. A.: Numerical modelling of the displacement and deformation of embedded rock bodies during salt tectonics: A case study from the South Oman Salt Basin, Geol. Soc. London, Spec. Publ., 363, 503-520, doi:10.1144/SP363.24, 2012a.

Li, S., Abe, S., Van Gent, H., Strozyk, F., Kukla, P. A., and Urai, J. L.: A new method to evaluate the salt rheology during long term ceep by inversion of numerical models of gravitational sinking of carbonate-anhydrite inclusions (stringers) in salt, in: Proceedings of the 7th Conference on the Mechanical Behavior of Salt?, Saltmech7 Paris, 16-19 April 2012, 215-220, 2012b. 
Liang, W., Yang, C., Zhao, Y., Dusseault, M. B., and Liu, J.: Experimental investigation of mechanical properties of bedded salt rock, Int. J. Rock Mech. Min. Sci., 44, 400-411, doi:10.1016/j.ijrmms.2006.09.007, 2007.

Lotze, F.: Steinsalz und kalisalze, Part I, in: Berlin: Gebruder Borntrager, 446 pp., 1957.

Martini, H. J.: Salzsättel und Deckgebirge, in: Frühjahrestagung "Salzlagerstätten" Der Deutschen Geologischen Gesellschaft in Goslar, Mai 1953, 823-836, 1953.

Mohr, M., Kukla, P. A., Urai, J. L., and Bresser, G.: Multiphase salt tectonic evolution in NW Germany: Seismic interpretation and retro-deformation, Int. J. Earth Sci., 94, 917-940, doi:10.1007/s00531-005-0039-5, 2005.

Müller, W. H., Schmid, S. M., and Briegel, U.: Deformation experiments on anhydrite rocks of different grain sizes: Rheology and microfabric, Tectonophysics, 78, 527-543, doi:10.1016/00401951(81)90027-5, 1981.

Poiate, E. J., Costa, A. M., Falcao, J. L., and Petrobrás, S. A.: Well Design for Drilling Through Thick Evaporite Layers in Santos Basin- Brazil, in: IADC/SPE Drilling Conference, 21-23 February 2006, Miami, Florida, USA, Society of Petroleum Engineers, 16, doi:10.2523/99161-MS, 2006.

Schenk, O. and Urai, J. L.: The migration of fluid-filled grain boundaries in recrystallizing synthetic bischofite: First results of in-situ high-pressure, high-temperature deformation experiments in transmitted light, J. Metamorph. Geol., 23, 695-709, doi:10.1111/j.1525-1314.2005.00604.x, 2005.

Schléder, Z., Urai, J. L., Nollet, S., and Hilgers, C.: Solutionprecipitation creep and fluid flow in halite: A case study of Zechstein (Z1) rocksalt from Neuhof salt mine (Germany), Int. J. Earth Sci., 97, 1045-1056, doi:10.1007/s00531-007-0275-y, 2008.

Scott Duncan, E. J., and Lajtai, E. Z.: The creep of potash salt rocks from Saskatchewan, Geotech. Geol. Eng., 11, 159-184, doi:10.1007/BF00531249, 1993.

Siemeister, G.: Primärparagenese und Metamorphose des Ronnenberglagers nach Untersuchung im Grubenfeld Salzdetfurth, Beihefte zum Geologischen Jahrbuch, Beiheft 62. Bundesanstalt für Bodenforschung, Geologische Landesämter der Bundesrepublik Deutschland, Hannover, 122 pp., 1969.

Spiers, C. J., Urai, J. L., Lister, G. S., Boland, J. N., and Zwart, H. $\mathrm{J}$. : The influence of fluid-rock interaction on the rheology of salt rock and on ionic transport in salt, Report over the period Nov. 1981-Dec. 1983, 131, 1983.

Strozyk, F., Van Gent, H., Urai, J. L., and Kukla, P. A.: 3D seismic study of complex intra-salt deformation: An example from the Upper Permian Zechstein 3 stringer, western Dutch offshore, Geol. Soc. London, Spec. Publ., 363, 489-501, doi:10.1144/SP363.23, 2012.

Strozyk, F., Urai, J. L., Gent, H. Van, Keijzer, M. De, and Kukla, P. A.: The internal structure of salt?: insights from a regional 3D seismic study of the Permian Zechstein 3 intra-salt stringer in the Northern Netherlands and its implications for salt tectonics, Interpretation 2, 101-117, doi:10.1190/INT-2014-0037.1, 2014.

Talbot, C. J. and Aftabi, P.: Geology and models of salt extrusion at Qum Kuh, central Iran, J. Geol. Soc. London., 161, 321-334, doi:10.1144/0016-764903-102, 2004.
Urai, J. L.: Water assisted dynamic recrystallization and weakening in polycrystalline bischofite, Tectonophysics, 96, 125-157, doi:10.1016/0040-1951(83)90247-0, 1983.

Urai, J. L.: Water-enhanced dynamic recrystallization and solution transfer in experimentally deformed carnallite, Tectonophysics, 120, 285-317, doi:10.1016/0040-1951(85)90055-1, 1985.

Urai, J. L. and Boland, J. N.: Development of microstructures and the origin of hematite in naturally deformed carnallite, Neues Jahrb. für Mineral. H., 2, 58-72, 1985.

Urai, J. L., Spiers, C. J., Peach, C. J., Franssen, R. C. M. W., and Liezenberg, J. L.: Deformation mechanisms operating in naturally deformed halite, Geol. en Mijnb., 66, 165-176, 1987.

Urai, J. L., Schléder, Z., Spiers, C. J., Kukla, P. A., Lange, J.-M., and Röhling, H.-G.: Flow and Transport Properties of Salt Rocks, in: Dynamics of Complex Intracontinental Basins: The Central European Basin System, Springer Science \& Business Media, 277-290, 2008.

Vackiner, A. A., Antrett, P., Stollhofen, H., Back, S., Kukla, P. A., and Bärle, C.: Syndepositional tectonic controls and palaeotopography of a permian tight gas reservoir in nw germany, J. Pet. Geol., 34, 411-428, doi:10.1111/j.1747-5457.2011.00512.x, 2011.

van Eekelen, H. A., Urai, J. L., and Hulsebos, T.: Creep of Bischofite, in: Proceedings, 1st Conference on the Mechanical Behaviour of Salt Pennsylvania, 15 pp., 1981.

Van Gent, H., Urai, J. L., and de Keijzer, M.: The internal geometry of salt structures - A first look using 3-D seismic data from the Zechstein of the Netherlands, J. Struct. Geol., 33, 292-311, doi:10.1016/j.jsg.2010.07.005, 2011.

Vysotskiy, E. A. and Kislik, V. Z.: Epochs of bischofite deposition in geologic history, Int. Geol. Rev., 29, 134-139, doi:10.1080/00206818709466130, 1987.

Warren, J. K.: Evaporites: Sediments, Resources and Hydrocarbons, Springer Science \& Business Media, Berlin Heidelberg, 1035 pp., 2006.

Williamson, M. D., Murray, S. J. J., Hamilton, T. A. P. A. P., Copland, M. A. A., Wil, M. D., Murray, S. J. J., Science, W. S. A., Hamilton, T. A. P. A. P., and Copland, M. A. A.: A Review of Zechstein Drilling Issues, in: Offshore Europe Conference in Aberdeen, Scotland, 9-12 September 1997, 189-196, doi:10.2118/51182-PA, 1998.

Wong, T. E.: Jurassic, in: Geology of the Netherlands, edited by: Wong, T. E., Batjes, D. A. J., and De Jager, J., Royal Netherlands Academy of Arts and Sciences, 107-125, 2007a.

Wong, T. E.: Cretaceous, in: Geology of the Netherlands, edited by: Wong, T. E., Batjes, D. A. J., and De Jager, J., Royal Netherlands Academy of Arts and Sciences, 127-150, 2007b.

Ziegler, P. A.: North-Western Europe: Tectonics and Basin Development, Geol Mijnb, 57, 589-626, 1978.

Zirngast, M.: The development of the Gorleben salt dome (northwest Germany) based on quantitative analysis of peripheral sinks, Geol. Soc. London, Spec. Publ., 100, 203-226, doi:10.1144/GSL.SP.1996.100.01.13, 1996. 
Zulauf, G., Zulauf, J., Bornemann, O., Brenker, F. E., Höfer, H. E., Peinl, M., and Woodland, A. B.: Experimental deformation of a single-layer anhydrite in halite matrix under bulk constriction, Part 2: Deformation mechanisms and the role of fluids, J. Struct. Geol., 32, 264-277, doi:10.1016/j.jsg.2009.12.001, 2010.
Zulauf, J. and Zulauf, G.: Coeval folding and boudinage in four dimensions, J. Struct. Geol., 27, 1061-1068, doi:10.1016/j.jsg.2005.04.003, 2005. 